\title{
THE LYGAEOIDEA SENSU LATO OF MAGALLANES REGION: CHECKLIST AND IDENTIFICATION KEY TO THE SPECIES
}

\author{
LOS LYGAEOIDEA SENSU LATO DE LA REGIÓN DE MAGALLANES: \\ LISTA DE ESPECIES Y CLAVE DE IDENTIFICACIÓN
}

Eduardo I. Faúndez ${ }^{1,2}$

\begin{abstract}
The species of Lygaeoidea and Idiostoloidea from Magallanes are listed and keyed. A total of 5 species have been recorded from Magallanes: 2 Lygaeidae, 2 Idiostolidae, 1 Rhyparochromidae, all of these phytophages and endemic. The first reports of synanthrompic interactions for Lygaeoidea in Magallanes are provided.

Key words: Heteroptera, Lygaeidae, Idiostolidae, Rhyparochromidae, Magallanes, Chile.

\section{RESUMEN}

Se listan las especies de Lygaeoidea e Idiostoloidea de la Región de Magallanes. Se entrega una clave de identificación ilustrada para las especies del grupo. Se registran en total 5 especies, 2 de Lygaeidae, 2 de Idiostolidae y una de Rhyparochromidae, todas nativas y fitófagas. Se reportan las primeras interacciones sinantrópicas para Lygaeoidea en Magallanes.

Palabras clave: Heteroptera, Lygaeidae, Idiostolidae, Rhyparochromidae, Magallanes, Chile.

INTRODUCTION

Lygaeoidea is one of the largest superfamilies on Heteroptera comprising about 4000 species on

500 genera (Schuh \& Slater, 1995). This group has a great diversity of trophic habits. Most of the species are phytophages, but several prey on other arthropods, and a small group, the Cleradini, feed

1 Entomology Department, North Dakota State University, Dept. 7650, P.O. Box 6050; Fargo, ND. ed.faundez@gmail.com, mariom.carvajal@gmail.com.

2 Departamento de Zoología Médica, Centro de Estudios en Biodiversidad (CEBCh), Magallanes, 1979, Osorno, Chile
\end{abstract}


on vertebrate blood (Schuh \& Slater, 1995). Several lygeoid bugs are considered of great economic importance (Sweet, 2000).

The taxonomic history of this group is highly complex; several taxa have been moved from different ranks from superfamily to tribe. Henry (1997), in his phylogenetic analysis clarified and stabilized the higher classification of the group.

In the Magallanes Region the knowledge of Lygaeoidea and related groups is poor, and most of the published accounts come from the results of old expeditions. Additionally, several species have been misidentified because of their similar appearance, and the lack of identification tools. The purpose of this work is to provide a checklist and a key of the species of Lygaeoidea and Idiostoloidea present in the Region.

\section{MATERIAL AND METHODS}

A bibliographic compilation of records of Lygaeoidea and Idiostolidae from Magallanes has been made. The checklist follows the following format: under the species name each reference is listed by the author, year in parenthesis, name of the species that author used, and exact localities in Magallanes that author provided. Immediately below the species name, the original combination is written in parenthesis. On systematics I follow Henry (1997). Photos were taken with a digital camera adapted to a stereoscopic microscope.

\section{RESULTS}

Lygaeoidea Schilling, 1829

Lygaeidae Schilling, 1829

Ischnorhynchinae Stål, 1872

Syzygitis poecilus (Spinola, 1852)

(Pachymerus poecilus Spinola, 1852)

Signoret (1885): Kliydocerys hyalinatus (Tierra del Fuego)

Breddin (1897): Ischnorhynchus hyalinatus

(Is. Navarino, Puerto Toro; Is. Hoste)

Haglund (1899): Ischnorhynchus hyalinatus
(Río Tres Pasos)

Scudder (1962): Polychisme poecilus (Is. Navarino: Puerto Williams, Seno Grandi; Is. Picton; Is. Bertrand)

Remarks: I have observed this species at the following localities: Parque Nacional Torres del Paine, Punta Arenas, Fuerte Bulnes.

Prado (2008) listed this species in the Artheneidae: Artheneinae, citing (Slater \& Brailovsky, 1986); however, Prado (2008) misinterpreted that paper. Slater \& Brailovsky (1986) placed Polychisme ferruginosus (Stål, 1874) in the Artheneinae and erected the new tribe Polychismini to include it. In the same paper, they resurrect the genus Syzygitis Berg to place S. poecilus and clearly state (p. 411) that $S$. poecilus is retained in the Ischnorhynchinae. Subsequently, Kerzhner (1997) again placed the genus Polychisme in the Ischnorhynchinae.

\section{Orsillinae Stål, 1872}

Nysius irroratus (Spinola, 1852) (Heterogaster irroratus Spinola, 1852) del Fuego)

Breddin (1897): Nysius irrorartus (Tierra

Remarks: I have observed this species at the following magellanic localities: Parque Nacional Torres del Paine, Puerto Natales, Punta Arenas, Fuerte Bulnes, Puerto del Hambre. Additionally this species was collected around window frames, inside homes in the region. It is likely that Nysius puberulus Berg, 1895, known only from Tierra del Fuego (Argentina), will eventually be found in the Magallanes Region.

Rhyparochromidae Amyot \& Serville, 1843

Rhyparochrominae Amyot \& Serville, 1843

Bergidia polychroma (Spinola, 1852)

(Pachymerus polychromus Spinola, 1852)

Arenas)

Berg (1895): Pamera polychroma (Punta 
Breddin (1897): Bergidia polychroma (Punta Arenas)

Haglund (Magallanes)

Scudder (1962): Bergidia polychroma (Is. Navarino, Puerto Williams; Tierra del Fuego; Punta Arenas)

Ashlock (1986): Bergidea polychroma[sic] (Magallanes)

Remarks: This species has been collected in Punta Arenas and Puerto Natales, in walls and around window frames of homes frequently in the evenings on outside.

Idiostoloidea Scudder, 1962

Idiostolidae Scudder, 1962

Idiostolus insularis (Berg, 1883) (Idiotropus insularis Berg, 1883)

Breddin (1897): Idiostylus insularis [sic] (Tierra del Fuego)
Scudder (1962): Idiostolus insularis (Is. Navarino, Seno Grandi, Puerto Williams; Is. Bertrand; Puerto Eden)

Schaefer \& Wilcox (1969): Idiostolus insularis (Is. Bertrand, Is. Navarino; Seno Grandi, Puerto Williams; Puerto Natales, Puerto Edén).

Carvajal \& Faúndez (2011): (Is. Bayly; Parque Nacional Torres del Paine).

Idiostolus schaeferi Faúndez, Carvajal \& Ashworth, 2014

Faúndez et al. (2014): Idiostolus schaeferi (Última Esperanza, Seno Guillardi)

Key to the species of Lygaeoidea and Idiostoloidea present in Magallanes Region

1(2) Profemora with two spines.......... Bergidia polychroma

2(1) Profemora unarmed 2

3(4) Head wide (Fig. 1), coloration grayish, black and yellow..... Nysius irroratus
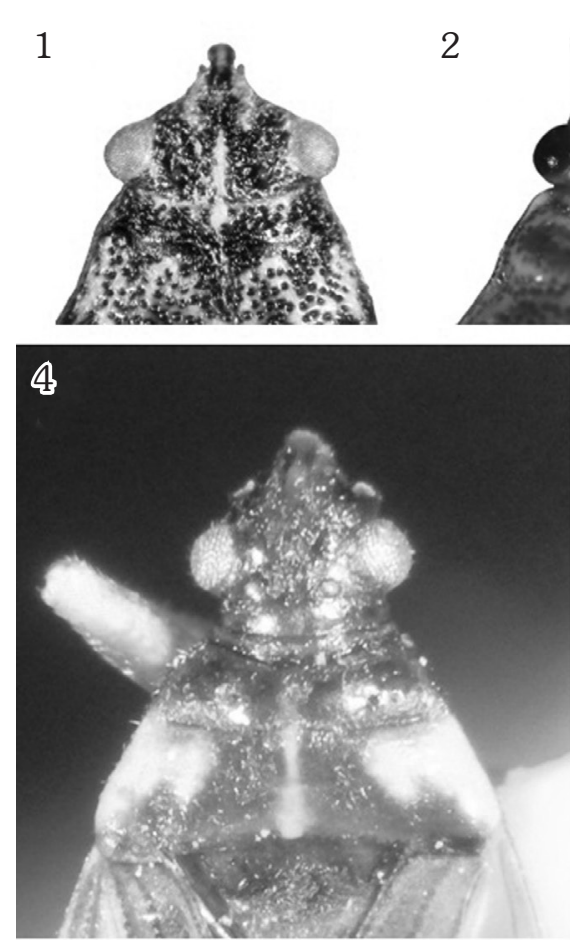
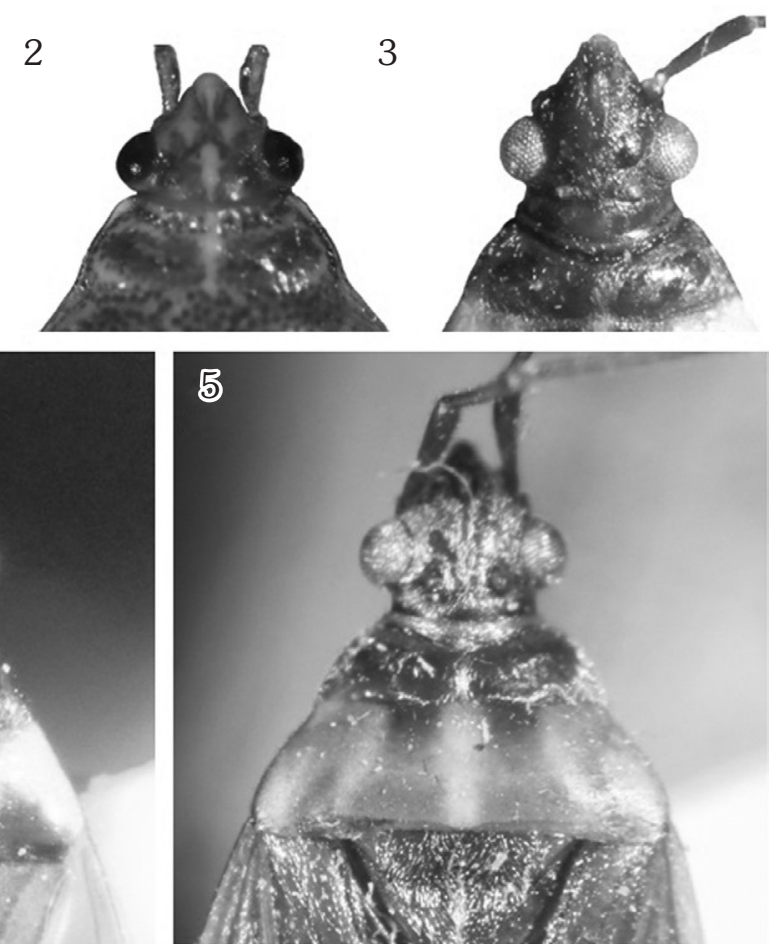

Fig. 1. Nysius irroratus, Head; Fig.2. Syzigitis poecilus, Head; Fig. 3. Idiostolus schaeferi, head; Fig. 4. Idiostolus schaeferi, pronotum; Fig. 5. Idiostolus insularis, pronotum. 
4(3) Head elongate (Figs. 2 and 3), coloration reddish, brownish, yellow and white..................5

5(6) Scutellum covered by dense punctation............................Syzygits poecilus

6(5) Scutellum unpunctated....................7

7(8) Pronotum subriangular, sides strongly inclined (Fig. 5). Idiostolus insularis

8(7) Pronotum trapezoid, sides less inclined (Fig. 4). Idiostolus schaeferi

\section{CONCLUSIONS}

There are 2 species of Lygaeidae, 2 of Idiostolidae, and 1 of Rhyparochromidae in Magallanes. All of the species present in Magallanes are phytophages, and endemic to the region.

The present report of Nysius irroratus and Bergidia polychroma in and around homes represent the first synanthropic records to Lygaeoidea in Magallanes. This behavior is probably the result of the bugs being attracted to sun-heated walls and warmer window frames of the homes during cold weather.

Further research is needed to learn more about the biology of these lygaeoids in Magallanes, and to asses their economic impact.

\section{ACKNOWLEDGEMENTS}

I thank David Rider (NDSU) for his bibliographic help and comments, and Thomas Henry (United States Museum of Natural History, Smithsonian Institution) for his suggestions and critical reading of the text.

\section{LITERATURE CITED}

Ashlock P. D. (1984). A Revision of the Bergidea Group: a problem in classification and biogeography (Hemiptera-Heteroptera: Lygaeidae). Journal of the Kansas Entomological Society, 57: 675-688.

Berg, C. (1895). Hemípteros de la Tierra del Fuego colleccionados por el Señor Backhausen. Anales del Museo Nacional de Buenos Aires, 4:195-206.

Breddin, G. (1897). Hemipteren. In: Hamburger Megalaensischen Sammelreise. Zweite
Lieferung, No. 4. Hamburg. $36+2$ pp., $1 \mathrm{pl}$.

Carvajal, M. A. \& E. I. Faúndez (2011). Notes on the distribution of Idiostolus insularis Berg, 1881 (Hemiptera: Heteroptera: Idiostolidae). Boletín de Biodiversidad de Chile, 6: 30-32.

Faúndez, E. I., M. A. Carvajal \& A. C. Ashworth (2014). Una nueva especie de Idiostolus Berg, 1883 (Hemiptera: Heteroptera: Idiostoloidea: Idiostolidae). Anales del Instituto de la Patagonia, 42(1): 71-75.

Haglund, C. J. E. (1899). Die Hemipteren der Schwedischen Expedition nach den Magellansländern 1895-97. Svenska Expeditionen Till Magellansländerna, 2(9):173-180.

Henry, T. J. (1997). Phylogenetic analysis of family groups within the infraorder Pentatomomorpha

(Hemiptera: Heteroptera), with emphasis on the Lygaeoidea. Annals of the Entomological Society of America, 90(3):275-301.

Kerzhner, I. M. (1997). East Palaearctic species of the genus Artheneis (Heteroptera: Lygaeidae). Zoosystematica Rossica, 6: 213-222

Prado, E. (2008). Conocimiento actual de Hemiptera-Heteroptera de Chile con lista de especies. Boletín del Museo Nacional de Historia Natural, 57:31-75.

Schaefer, C. W., \& D. Wilcox (1969). Notes on the Morphology, Taxonomy, and Distribution of the Idiostolidae (HemipteraHeteroptera). Annals of theEntomological Society of America, 62(3): 485-502.

Slater, J. A., \& H. Brailovsky (1986). The first occurrence of the subfamily Artheneinae in the Western Hemisphere with the description of a new tribe (Hemiptera: Lygaeidae). Journal of the New York Entomological Society, 94: 409-415.

Schuh, R. T. \& J. A. Slater (1995). True bugs of the World (Hemiptera: Heteroptera): Classification and Natural History. Cornell University Press, Ithaca, New York, $336 \mathrm{pp}$.

Scudder, G. G. E. (1962). Results of the Royal Society Expedition to southern Chile, 
1958-59: Lygaeidae (Hemiptera), with the description of a new subfamily. The Canadian Entomologist, 94: 1064-1074.

Signoret, V. (1885). Liste des Hémiptères recueillis a la Terre de Feu par la mission de la Romanche et description des espèces nouvelles. Annales de la Société
Entomologique de France, (6)5:63-70.

Sweet, M. H. (2000). Economic importance of the seedbugs and the chinchbugs (Lygaeoidea) Chapter 6. Pp.143-264 in C.W, Schaefer and A R. Panizzi (eds.) Heteroptera of Economic Importance. CRC Press, Boca Raton, Florida. 
